\title{
PEMBERDAYAAN HUKUM DALAM RANGKA MEWUJUDKAN INDONESIA SEBAGAI NEGARA HUKUM DAN EMPOWERING STATE
}

\author{
Oleh: \\ Galang Asmara
}

Selama ini pandangan tentang hukum di Indonesia dipengaruhi oleh ajaran bahwa hukum merupakan sarana pembaharuan masyarakat atau sarana rekayasa sosial Law as a tool of social engeneering). Ajaran yang merupkan modifikasi dari ajaran Rucoe Pound ini dikembangkan oleh Prof. Mochtar Kusumaatmadja dari Universitas Padjadjaran Bandung telah menjadi amutan Pemerintah di masa Orde Baru untuk mendukang program pembangunan Dengan pandangan tersebut, hukum cendrung menjadi alat penguasa untuk melegitimasikan apa saja yang dikehendaki untuk diperbuat terhadap rakyat. Pandangan imi dalam batas-batas dan tahap tertentu dapat membawa kemasalahatan, akan tetapi manakala kontrol terhadap kekuasaan lemah, pandangan ini akan menimbulkan kemudaratan dan kesengsaraan bagi rakyat. Oleh sebab itu diperlukan suatu konsep baru tentang fungsi hukum. Hukum pada saat ini hendaknya bukan semata-mata alat rekayasa masyarakat melainkan sebagai instrumen mengontrol kekuasaan oleh rakyat.

\section{Pendahuluan}

Kenyataan kasat mata yang tak terbantahkan yang dapat disaksikan saat ini adalah penegakan hukum yang sangat buruk. Oleh sebab itu tidak mengherankan apabila masyarakat enggan menghormati hukum, karena mereka menganggap hukum tidak lagi dapat memberikan jaminan keamanan dan ketertiban. Hukum seolah-olah tidak lagi dipercaya untuk dapat menyelesaikan masalah-masalah yang terjadi di tengah-tengah kehidupan masyarakat berbangsa dan bernegara. Kepastian hukum menjadi dipertanyakan. Semoboyan Fiat Justitia Pereat Mundus ("walaupun dunia akan runtuh, hukum harus tetap ditegakkan") hanyalah semboyang pemanis di bibir pengacara belaka. Hukum seolah-olah benar-benar telah lumpuh menghadapi berbagai pelanggaran hukum dan hak asasi manusia. Pernyataan di atas bukanlah isapan jempol belaka. Potret suram kondisi bangsa Indonesia tersebut dapat ditunjukkan dengan berbagai kasus yang tidak ditangani dengan baik seperti: (1) Kasus penyalahgunaan dana reboisasi oleh Prayugo Pangestu Cs yang diperkirakan telah merugikan keuangan negara sebesar Rp.195 milyar;; (2) Kasus yang melibatkan Ginanjar Kartasasmita Cs yang diduga telah melakukan tindak pidana korupsi dalam technological contraces PT.Pertamina dengan PT Ustrindo Petro Gas. Kerugian negara diperkirakan 
mencapai 23,3 juta dollar AS. Perkara ini mulai disidik Maret 2001 dan hingga saat ini tidak jelas penyelesaiannya (Kompas, 4/12/2001); (3) Terakhir, dapat disaksikan betapa lambannya penyelesaian masalah dalam kasus "BLBI" dan "Bulog Gate".

Diskripsi kasus-kasus di atas adalah segelintir kasus dari ribuan kasus yang lain yang memperlihatkan kepada kita tentang begitu lemahnya penegakan hukum di negeri ini. Hukum seolah-olah sudah tidak berdaya lagi mengatasi permasalahanpermasalahan hukum yang seharusnya menjadi tugasnya.

$\mathrm{Di}$ lain pihak moral para penyelenggara negara dan para penegak hukum kian merosot, hal ini dibuktikan dengan maraknya praktik-praktik Korupsi, Kolusi dan Nepotisme. Masih terngiang di telinga kita, bahwa di tahun 2000 dunia internasional telah menilai korupsi di Indonesia paling parah di Asia. Penilaian ini dibuat oleh "Political and Economic Risk Consultation" (PERC) atau Badan Konsultasi Risiko Ekonomi dan Politik terhadap 527 ekspatriat di seluruh wilayah Asia (Bali Post, 25/3-2000). Predikat tersebut tetap dipertahankan hingga tahun 2002 ini, bahkan disinyalir kian parah oleh PERC (Bali Post, 11 Maret 2002).

Korupsi di Indonesia bahkan sejak lama telah merambah ke dunia peradilan. Kita masih ingat, bahwa di tahun 1998 Daniel Kaufman dalam Laporan Bureaucratic and Judiciary Bribery dikatakan bahwa tingkat korupsi di peradilan Indonesia adalah paling tinggi diantara negara-negara Ukraina, Venezuela, Rusia, Kolombia, Mesr, Yordania, Turki, malaysia, Brunei, Afrika Selatan, Singapura, dan lain-lain. Celaanya, korupsi di peradilan dianggap sebagai hal yang biasa. Banyak pengacara yang tidak malu-malu lagi meiwarkan sejumlah uang kepada hakim dan jaksa. Bahkan dalam bentuk yang berbeda, ada juga pengacara yang "menggaji" hakim bulanan. Sementara pada saat yang bersamaan, hakim jaksa, polisi juga panitera, tidak merasa risih pula untuk meminta uang dari pengacara. Ibaratnya, jika dulu korupsi dilakukan dengan diam-diam, kini dilakukan terbuka dan terang-terangan. Hingga kini tidak ada jaminan jika praktikpraktik $\mathrm{KKN}$ di lembaga peradilan itu sudah usai. Sebagian masyarakat menilai Pengadilan bukan lagi tempat mendapatkan keadilan melainkan bursa keadilan. Siapa yang bisa memberi banyak, akan mendapatkan keadilan yang diinginkan.1

Untuk menggambarkan keadaan tersebut kiranya tepat ungkapan Marcus Lukman yang menyatakan, bahwa seluruh persendian hukum dan tatanan hukum tampaknya terkena penyakit REMATIK Rusak Etik, Moral, Akhlak, Tekad, Intelegensi dan Kearifan. Akibatnya yang mengedepan bukanlah perilaku hukum yang beradab melainkan mundur ke zaman jahiliyah-homo homini lupus, annomali, dan chaos (Marcus Lukman, 2002:1) 


\section{Pemberdayaan Hukum Melalui Perubahan Paradigma Tentang Fungsi Hukum}

Kondisi seperti yang digambarkan di atas, menunjukkan betapa hukum tidak berdaya mengatur kehidupan bermasyarakat, berbangsa dan bernegara sesuai dengan cita-cita hukum itu sendiri untuk mewujdukan keadilan, kepastian dan kesejahteraan bagi masyarakat. Oleh sebab itu diperlukan suatu upaya untuk memberdayakan hukum.

Memberdayakan hukum artinya mengupayakan berfungsinya hukum sebagai sarana pengendali kehidupan berpribadi, bermasyarakat, berbangsa, dan bernegara untuk memanusiakan diri manusia ke nalar kemanusiaannya yang membutuhkan rasa aman, damai, tenteram, tertib, pasti, benar, dan berkeadaban Pemberdayaan hukum bertujuan membudayakan perilaku hukum sehingga mampu membentuk pemikiran, perasaan, kehendak, sikap perilaku, dan perbuatan hukum yang sesuai dengan tujuan hukum, yakni terciptanya keadilan, kepastian dan kesejahteraan bagi masyarakat.

Persoalannya siapakah yang perlu dibudayakan perilaku hukumnya, dan dengan cara bagaimana memberdayakan hukum sehingga tercipta kesadaran dan kepatuhan hukum. Kesadaran dan kepatuhan hukum akan terwujud manakala pada diri individu dan kelompok masyarakat terbentuk pengetahuan, pemahaman, dan penghayatan yang mapan tentang manfaat dan tujuan hukum, yang atas dasar itu, terekspresikan pemikiran, perasaan, sikap, watak, perilaku, dan perbuatan yang mentradisi untuk mematuhi peraturan hukum termasuk menyelesaikan sengketa sesuai koridor hukum yang berlaku.

Nampaknya untuk memecahkan persoalan ini tidak cukup dengan mencari pemecahan secara pragmatis dan parsial melainkan harus dicari dari pendekatan filosofis tentang paradigma dan pandangan tentang hukum yang dianut selama ini.

Selama ini pandangan tentang hukum di Indonesia dipengaruhi oleh ajaran bahwa hukum merupakan sarana pembaharuan masyarakat atau sarana rekayasa sosial (Law as a tool of social engeneering). Ajaran yang merupkan modifikasi dari ajaran Rucoe Pound ini dikembangkan oleh Prof. Mochtar Kusumaatmadja dari Universitas Padjadjaran Bandung dan telah menjadi anutan Pemerintah di masa Orde Baru untuk mendukung program pembangunan (Otje Salman, 1987:17,35; Lihat pula Lili Rasjidi, 1993:83)

Dengan pandangan tersebut, mau tidak mau kita menempatkan hukum identik dengan kemauan penguasa, karena hukum di sini dipergunakan sebagai sarana bagi penguasa untuk mengubah tatanan perikehidupan masyarakat ke arah yang dikehendaki. Menurut hemat penulis, pandangan ini dalam batas-batas dan tahap tertentu dapat membawa kemasalahatan, akan tetapi manakala kontrol terhadap kekuasaan lemah, pandangan ini akan menimbulkan kemudaratan dan 
kesengsaraan bagi rakyat. Beberapa sisi negatif yang muncul dalam penerapan pandangan sosial engenering tersebut dan yang telah dialami oleh bangsa Indonesia antara lain adalah; Masyarakat ditempatkan pada posisi sebagai obyek yang harus diatur dan direkayasa. Dalam bahasa lain masyarakat hanya semata-mata sebagai obyek pembangunan, bukan subyek pembangunan. Sementara penguasa sendiri dapat bertindak apa saja menurut kehendaknya dengan mempergunakan legalitas hukum. Rakyat ditempatkan pada posisi yang berhadap-hadapan dengan penguasa. Dalam posisi yang demikian, rakyat yang lemah bila berhadapan dengan Penguasa yang kuat, akan menjadi pasif dan serba menunggu seraya tunduk pada kehendak penguasa. Di kalangan para pejabat pemerintahan yang melaksanakan fungsi pemerintahan dan pembangunan baik di tingkat pusat maupun daerah, berkembang budaya Manajekemn Birokrasi Otokratik (MBO), Feodalistik, KKN, Komersialisasi Jabatan dan sebagainya yang menyebabkan masyarakat tidak terayomi kepentingannya ketika berurusan dengan instansi pemerintah yang diharapkan menjalankan Manajemen Birokrasi Kerakyatan (MBK);

Di kalangan aparatur penegak hukum akan terbentuk budaya penggunaan kewenangan repressif. Pada masa lalu seringkali terekspose di media masa terjadinya kasus-kasus penangkapan, penahanan, interogasi, penggeledahan, penyitaan barang bukti, penuntutan, peradilan, dan pengambilan putusan pengadilan yang menyimpangi kaidahkaidah hukum, mengakibatkan terkoyaknyan perasaan keadilan hukum dalam masyarakat;

Bagi anggota Dewan Perwakilan rakyat di tingkat Pusat miaupun daerah yang melaksanakan fungsi penyambung lidah rakyat berkembang budaya hipokrit, memanipulasi kepentingan pribadi dan golongan seolah-olah kepentingan rakyat.

Hal-hal tersebut merupakan ekses-

ekses yang ditimbulkan dari penerapan pandangan yang menempatkan hukum sebagai sarana rekayasa sosial. Untuk mengatasi dan menghindari terjadinya berbagai ekses tersebut, maka jalan harus ditempuh adalah kontrol yang ketat terhadap segala kebijaksanaan pemerintah oleh rakyat. Dengan kata lain fungsi hukum sebagai social engenering harus disertai dengan kontrol yang ketat pemerintah. Social engenering tanpa kontrol yang ketat terhadap penguasa sama saja dengan menciptakan kesewenangwenangan.

Untuk diketahui, berdasarkan hasil evaluasi "Masyarakat Transparansi Indonesia (MPTI) di bawah Pimpinan Mkar'ie Muhammad, dari 528 buah Keputusan Presiden yang dibuat oleh Soeharto, minus 118 buah Keputusan Presiden hasil ratifikasi perjanjian internasional selama periode 5 (lima) tahun (1993-1998), terdapat 79 buah dinilai bermasalah (itu baru selama 5 tahun, apalagi selama 32 tahun) Puluhan 
Keputusan Presiden yang bermasalah tersebut menjadi bukti tentang penggunaan kekuasaan yang tidak terbatas oleh penguasa dalam menentukan materi dari produk hukum untuk diabdikan bagi kepentingan penguasa dan para kroninya (Indah Sri Utari, dalam Wajah Hukum di Era Reformasi, 202:74), Keputusan Presiden yang bermasalah tersebut berisi pengaturan yang sarat dengan kehendak penguasa waktu itu. Namun apabila hal ini dilihat dari perspektif fungsi hukum sebagai sarana pembaharuan masyarakat, maka Keputusan Presiden tersebut tidaklah dapat dipermasalahkan.

Paradigma Law as a tool of social engeneering hanya akan menemui harapannya manakala penguasa memiliki hati nurani dan niat yang tulus untuk menciptakan kemakmuran rakyat dan menghindari penggunaan kekuasaan untuk kepentingan-kepentingan politik atau golongan tertentu. Dengan kata lain, soscial engenering akan menimbulkan kemasalahatan manakala diterapkan di dalam pemerintahan baik (Clean Government dan Good Governance) disertai dengan kontrol yang baik dari masyarakat terhadap penguasa. Paradigma yang harus dikembangkan terhadap fungsi hukum, adalah bahwa selain hukum berfungsi sebagai soscial controle dan social engenering harus pula dikembangkan paradigma hukum $\mathrm{La}$ as tool of government controle.

Pandangan yang lain yang berpengaruh terhadap penegakan hukum di tanah air selama ini adalah faham yang selalu mengaitkan penegakan hukum dengan faktor-faktor lain di luar hukum yang akan terkena dampak dari penerapan hukum, yakni faktor sosial budaya, politik, ekonomi, dan keamanan. Menurut faham ini, hukum tidak dapat diterapkan begitu saja tanpa harus memperhatikan dampaknya terhadap kenyataan-kenyataan sosial seperti aspek-aspek kehidupan sosial budaya, politik, ekonomi, dan keamanan. Manakala penerapan hukum akan berdampak negatif besar terhadap aspekaspek tersebut, maka hukum tidak dapat diterapkan seperti bunyi normanya.

Pandangan ini, menurut hemat penulis juga dalam batas-batas dan tahaptahap tertentu dapat menimbulkan kemasalahatan. Namun penerapan faham ini di dalam negara yang pemerintahnya sangat kuat juga dapat menimbulkan dampak negatif, karena penguasa yang kuat atau sebaliknya, penguasa yang terlalu lemah dapat saja merekayasa faktor-faktor di luar hukum tersebut demi kepentingan penguasa atau kelompok tertentu sehingga hukum tidak dapat diterapkan.

Jangankan undang-undang biasa, undang-undang dasar saja dapat disimpangi apabila faktor-faktor di luar hukum itu menjadi patokan di dalam penerapan kaidah hukum. Sebagai contoh: Jatuhnya Soeharto dari tampok kekuasaannya di tahun 1998 dan Habibie di tahun 2000 tidak dapat dicari dasar yuridisnya di dalam UUD 1945. Bukankah Presiden yang mendapatkan dukungan mutlak di MPR 
dan baru beberapa bulan diangkat terpaksa harus menyerahkan jabatannya kepada Wakil Presiden dengan alasan yang dibuatbuat alias rekayasa. Demikian pula, Habibie yang menurut konstitusi seharusnya dapat melanjutkan kekuasaannya sampai tahun 2003 ketika masa jabatan Presiden yang digantinya berakhir, akan tetapi terpaksa harus menyelenggarakan Pemilu dan meletakkan jabatanya setelah pertanggungjawabannya ditolak oleh MPR yang notabene alasan penolakan tersebut telah direkayasa oleh kemauan dari kekuatan-kekuatan politik tertentu.

Proses pemberhentian Presiden Gus Dur melalui memorandum, yang seolaholah nampak konstitusional juga patut diduga berjalan di atas rekayasa kekuatan politik tertentu. Keadaan ini adalah wajar, jika dilihat dari pandangan yang terakhir, bahwa dalam penerapan hukum harus memperhatikan faktor-faktor di luar hukum. Rakyat tidak merasa bersalah telah melanggar konstitusi yang dibuatnya sendiri karena mereka menganggap daripada akan menimbulkan dampak negatif yang luas terhadap kehidupan sosial ekonomi politik, pertahanan dan keamanan negara, hukum tidak perlu diterapkan.

Patut diduga, bahwa tidak dapat dituntutnya para pelaku pelanggaran hukum dan HAM selama ini bukan sematamata karena alasan teknis yuridis yakni sulitnya melakukan pembuktian, ataupun karena faktor hukum yang kurang baik, faktor sarana dan prasarana yang tidak memadai, ataupun karena sumber daya manusia yang tidak canggih, akan tetapi karena adanya pengaruh dari faham yang terakhir ini sebagai alasan pembenar, karena dianggap apabila penegakan hukum dilakukan dapat menimbulkan dampak negatif besar terhadap perekonomian dan kemanan maupun politik dalam negeri.

Bahaya yang ditimbulkan oleh aliran ini, menurut hemat penulis adalah, bahwa kita tidak akan pernah menerapkan asas supermasi hukum. Kita tidak akan pernah menghormati hukum seperti yang dikehendaki ketika dibuatnya. Oleh sebab itu faham ini dapat melecehkan salah satu sendi terpenting dari negara hukum, yakni asas legalitas.

Ke depan, kita hendaknya mengembangkan paradigma bahwa perhatian terhadap faktor-faktor di luar hukum terutama ditekankan ketika hukum itu dibuat, sedangkan ketika hukum diterapkan hendaknya berlaku prinsip "lokomotif harus berjalan di atas rel hukum" bukan rel yang harus mengikuti lokomotif. Apabila ini yang terjadi maka jangan harap tujuan berbangsa dan bernegara akan pernah tercapai. Yang akan terjadi justru kehancuran. Bayangkan apabila lokomotif dari gerbong kereta api berlari kencang kesana kemari sesuai dengan kehendaknya tanpa mengikuti relnya. Bukankah kereta api itu akan terjungkal atau akan menabrak rumahrumah dan tanaman penduduk.

Hukum hendaknya ditaati oleh semua fihak selama hukum itu tidak 
diubah. Apabila hukum tidak lagi dianggap memberikan rasa adil di dalam masyarakat maka hukum itu hendaknya diubah melalui jalur yang benar. Itulah makna dari sebuah negara hukum. Dalam suatu negara hukum, menurut hemat penulis keadilan harus berada dalam kepastian.

\section{Upaya Pemberdayaan Hukum Melalui Lembaga Ombudsman}

Lebih dari 100 (seratus) negara pada saat ini telah membentuk lembaga ombudsman. Sejak kelahirannya yang pertama kali di Swedia dalam tahun 1809 lembaga ini telah menjadi tumpuan harapan penegakan konsep negara hukum dan konsep demokrasi. Keberadaan lembaga ombudsman pada saat ini juga dapat dikaitkan dengan upaya menciptakan good governance.(Galang Asmara dalam Mahkamah, 2002:24)

Fungsi yang utama dari lembaga ombudsman adalah sebagai sarana kontrol masyarakat terhadap penggunaan kekuasaan oleh pemerintah (Paulus Effendi Lotulung, 1986:23) sekaligus juga sebagai sarana perlindungan hukum bagi rakyat (Philipus M.Hadjon, 1987:2). Lembaga ini menurut pendapat penulis dapat dipandang sebagai salah satu pilar konsep negara hukum, karena berdasarkan kenyataannya ombudsman ini sangat berwibawa dan sangat konsen dengan penegakan hukum. Itulah sebabnya, tidak pernah ada di dunia ini sebuah lembaga ombudsman dibubarkan. Sekali ia didirikan, maka ia tetap eksis, bahkan telah berkembang sedemikian rupa. Di negara-negara yang maju dan modern seperti Swedia, Inggris, Perancis, Australia, New Zealand dan lainlain lembaga ini sangat bergengsi sebagai tumpuan harapan masyarakat untuk menyampaikan segala bentuk pelanggaran yang dilakukan oleh pemerintah (administrasi) terhadap rakyatnya. Ombudsman benar-benar seolah-olah telah menjadi tangan kanan rakyat untuk menyelidiki dan mengontrol kesalahankesalahan pemerintah.

Meskipun Ombudsman hanya mampu memberikan rekomendasi tanpa ada kekuatan mengikat secara yuridis, namun berdasarkan pengalaman di negaranegara maju rekomendasi Ombudsman sangat dihormati. Hal ini tidak lain karena Ombudsman mampu menunjukkan kesalahan-kesalahan dan pelanggaranpelanggaran pemerintah secara obyektif. $\mathrm{Di}$ lain pihak Parlemen biasanya sangat memperhatikan nasihat-nasihat rekomendasi-rekomendasi sebagai salah satu tolok ukur di dalam menilai kinerja pemerintah.

Oleh sebab itu dalam rangka penegakan hukum di Indonesia yang sedang gamang ini, keberadaan lembaga ombudsman hendaknya disambut dan didukung sepenuhnya oleh setiap komponen bangsa. Menurut hemat penulis ada beberapa keuntungan dari keberadaan ombudsman:

Bagi rakyat, Ombudsman merupakan sarana kontrol terhadap pemerintah, 
sehingga dapat mencegah prilaku pemerintah yang merugikan warga.

bagi pemerintah, ombudsman merupakan partner yang dapat dimintakan nasibat dalam memperbaiki kinerjanya. Bagi bangsa, Ombudsman merupakan sarana untuk menciptakan pemerintahan yang bersih, transparan, bertanggung jawab.

Bagi penegak hukum, Membantu aparatur penegak hukum di dalam penegakan hukum, sekaligus untuk menegakkan eksistensi negara hukum dan demokrasi.kesejahteraan.

\section{Pemberdayaan Hukum Menuju Empowring State Konsep empowering state} merupakan konsep yang relatif baru. Konsep ini ada disinggung oleh Muh. Guntur dalam Disertasinya berjudul Pengaturan Hukum dan Pelaksanaan Tata Niaga Produk Pertanian (Muh.Guntur, 2002) Menurut hemat penulis, pada dasarnya konsep empowering state menghendaki negara tidak lagi mengkooptasi rakyat melainkan negara hendaknya lebih banyak berperan sebagai penyedia sarana pendukung untuk kegiatan rakyat. Negara lebih diwajibkan untuk menciptakan kondisi yang kondusif bagi kegiatan warga masyarakat. Negara hendaknya tidak terlalu banyak ikut campur dalam urusan-urusan rakyat. Dengan kata lain rakyat hendaknya diberi peluang yang lebih besar untuk mengurus dirinya sendiri. Kalau boleh meminjam istilah Bagir Manan, "Negara atau
Pemerintah harus bertindak selaku pemberi fasilitas atau kemudahan-kemudahan yang mendorong tumbuhnya inisiatif dan kreatifitas" (Bagir Manan, 1994:4) Dalam kegiatan ekonomi, rakyat hendaknya diberi peluang yang besar untuk menguasai alatalat produksi. Jadi rakyat hendaknya diberdayakan.

Konsep ini kiranya paralel dengan konsep civil society yang telah mendasari cita-cita kelahiran orde reformasi. Dalam teori fungsi negara yang dikemukakan oleh Adam Smith, negara (pemerintah) memang dibatasi dalam tiga fungsi, yakni: (1) tugas menjaga keamanan dan ketertiban (security and order), (2) tugas menegakkan keadilan (justice enforcement), (3) tugas membangun sarana dan prasarana atau infra struktur publik (public infrastructure development) (Rudhi Prasetya, 1997:19).

Apa yang dikemukakan oleh Adam Smith tersebut kiranya sangat tepat sebagai paradigma yang dianut bangsa Indonesia ke depan, karena pandangan tersebut seirama dengan konsep paradigma falsafati tentang fungsi hukum seperti yang telah dikemukakan di depan, dan cocok pula dengan paradigma konsep civl society, serta dengan paradigma futuristik tentang globalisasi dan era perdagangan bebas. Negara hendaknya tidak terlalu mendikte, apalagi mengkooptasi urusan-urusan warga dalam dunia usaha maupun urusan-urusan sosial. Paradigma tersebut hanya cocok di masa lalu ketika bangsa Indonesia masih bodoh karena baru terlepas dari cengkraman penjajahan. Fungsi negara 
yang perlu dikembangkan adalah seperti yang dikemukakan oleh Adam Smith tersebut, atau apa yang dikemukakan oleh L.A. Geelhoed. Menurut Geelhoed ada empat fungsi negara, yakni: (1) fungsi pengaturan (de Ordenende), (2) fungsi penyelenggaraan (de Presterende), (3) fungsi pengendalian (de Sturende), dan (4) fungsi perwasitan (de Arbitererende) [L.A. Geelhoed, 1983:31-58). Menurut hemat penulis, baik Adam Smith maupun L.A. Geelhoeld tidak menghendaki adanya campur tangan yang luas. Mereka menghendaki adanya campur tangan namun sangan terbatas sekali. Campur tangan negara pada hakikatnya memang harus ada, akan tetapi dalam tahap-tahap perkembangan tertentu dari suatu negara harus sekecil mungkin. Campur tangan negara yang luas dibutuhkan ketika rakyat memang tidak berdaya, bodoh dan miskin. Akan tetapi manakala rakyat sudah dalam taraf maju, maka campur tangan negara harus sekecil mungkin. Campur tangan negara, memang tidak dapat dihindari, karena negara memiliki tangung jawab dalam rangka mewujudkan tujuan negara. Akan tetapi campur tangan negara harus diberi proporsi yang sesuai dengan tahap perkembangan rakyat suatu negara.

Menurut hemat penulis, pada tahap sekarang ini, campur tangan negara terhadap kehidupan rakyat Indonesia harus dibatasi, karena selain rakyat Indonesia sudah tidak lagi dapat dikatakan sebagai rakyat yang bodoh dan miskin, juga berdasarkan pengalaman masa lalu penguasa telah memanfaatkan campur tangtannya untuk kepentingan-kepentingan golongan rakyat tertentu dan untuk kepentingan politik tertentu.

Penulis mendukung sepenuhnya apa yang dikemukakan oleh Peter Mahmud Marzuki yang menyatakan bahwa perlu dibangun interaksi saling menguntungkan antara pemerintah dan pasar, bukan campur tangan pemerintah yang bersifat mengekang versus "laisser-faire" pasar bebas (Peter Mahmud Marzuki, 1997:4)

Bertolak dari pandangan di atas, maka yang terpenting kelak campur tangan negara terutama diarahkan pada penegakan hukum secara baik sehingga tercipta suatu konidi yang kondusif bagi segala aktivitas masyarakat. Tidak adanya penegakan hukum yang baik hanya akan menyebabkan ketidakpastian berusaha dan ketidakpastian dalam masyarakat melangkah untuk meraih masa depan. Dalam hubungan ini, maka penegakan hukum sekaligus pemberdayaan hukum merupakan conditio sine quanon bagi terwujudnya negara hukum dan empowering state

\section{Penutup}

Dari paparan di muka, dapat ditarik beberapa kesimpulan sebagai berikut: Faham filsafati tentang fungsi hukum yang menyatakan "hukum sebagai sarana pembaharuan masyarakat atau rekayasa sosial" (Law as a tool of Social Engeneering) akan menimbulkan kemaslaahatan bagi rakyat apabila 
diimbangi dengan kontrol yang baik terhadap penguasa. Oleh sebab itu paradigma tentang fungsi hukum tersebut hendaknya dibarengi prinsip "law as a tool of government control"

Mempertimbangkan faktor-faktor di luar hukum, dalam rangka proses penegakan hukum, seperti faktor sosial budaya, politik, ekonomi dan pertahanankemanan dapat melecehkan asas legalitas yang merupakan salah satu sendi konsep negara hukum.

Untuk memberdayakan hukum pada masa mendatang, segenap bangsa Indonesia, baik para penyelenggara negara, para penegak hukum, pemeimpin pemerintahan, para wakil rakyat, pengajar hukum, para penegak hukum, mahasiswa dan segenap anggota masyarakat, harus berupaya untuk menyembuhkan penyakit REMATIK (Rusak Etik, Moral, Akhlak, Tekad, Intelegensi dan Kearifan) di kalangan bangsa Indonesia.

Lembaga Ombudsman mempunyai peranan yang strategis sebagai salah satu sarana penegakan hukum dan pemberdayaan hukum, sarana kontrol terhadap penguasa, sarana untuk menegakkan konsep negara hukum dan demokrasi, serta sarana untuk menciptakan pemerintahan clean government dan good governance (pemerintah yang bersih dan pemerintahan yang baik).

Perak Penegakan dan pemberdayaan hukum merupakan conditio sine quanon bagi terwujudnya negara hukum dan empowering state.

\section{DAFTAR PUSTAKA}

Effendi Lotulung, Paulus, Beberapa Segi Kontrol trhadap Pemerintah, Citra Aditya Bhakti, 1994.

Geelhoed, L.A., De Intervenierende Staat (Aanzet voor een instrumentenleer), Staatsuitgeverij, s'Gravenhage, 1983.

Guntur, Muh., Pengaturan Hukum dan Pelaksanaan Tata Niaga Produk Pertanian, Disertasi, Program Pascasarjana Universitas Airlangga, Surabaya, 2002.

Hadjon, Philpus, Perlindungan Hukum bagi Rakyat, Erlangga, Surabaya, 1987.

1ICW, Menyingkap Tabir Mafia Peradilan (Hasil Monitoring Peradilan ICW), Jakarta, Juni 2001.

Kusumatmadja, Mochtar, Hukum, Masyarakat dan Pembinaan Hukum Nasional, Bina Cipta, bandung, 1976.

- Fungsi Hukum dan Perkembangan Hukum dalam Pembangunan Nasional, Binacipta, Bandung.

Manan, Bagir, "Pembinaan Hubungan Antara Lembaga-lembaga Hukum dan Pelayanan Hukum", Makalah 
Seminar Hukum Nasional VI, BPHN Departemen Kehakiman RI, Jakarta, 25-29 Juli 1994.

Marzuki, Peter Mahmud, "Kerangka Pemikiran Hukum Daalam Ekonomi Pasar", Makalah PPsUnair, Surabaya, 1997

Otje Salman, Ikhtisar Filsafat Hukum, Armico, Bandung, 1986.

Pound, Roscoe, Pengantar Filsafat Hukum, terjemahan Drs. Mohammad Radjab, Bhratara, Jakarta, 1972.

Tugas Hukum, terjemahan Drs. Mohamad Radjab, Bhratara, Jakarta, 1975.

Prasetya, Rudhi, "Analisa Ekonomi Terhadap Hukum Kontrak Dalam Menyongsong Era Globalisasi”, dalam Jurnal Hukum Bisnis Volume 2 Tahun 1997, Jakarta, 1993

Rasjidi, Lili, Dasar-dasar Filsafat Hukum, Citra Aditya, Bakti, 1993.

Rahardjo, Satjipto, Wajah Hukum di Era Reformasi, (Kumpulan Karya Ilmiah Menyambut 70 tahun Satjipto Rahardjo, Citra Aditya Bakti, 2002)
Bali Post, 23 Maret 2000

Bali Post, 11 Maret 2002

Kompas, 4 Desember 2001 